\title{
Using Innovative Approach to Forming Foreign Language Professional Communicative Competence at Bachelors of Science in Mining Engineering
}

\author{
Sergey Lebedintsev ${ }^{1^{*}}$, Lyubov Fedyanina ${ }^{2}$, and Vyacheslav Gustov ${ }^{1}$ \\ 1. T.F. Gorbachev Kuzbass State Technical University, 650000, 28 Vesennyaya St., Kemerovo, Russia \\ 2. Kemerovo State University, 650043, 6 Krasnaya St., Kemerovo, Russia
}

\begin{abstract}
This article discusses the authors' methods and techniques in the system of innovative pedagogical technologies proposed by postsecondary foreign language teachers providing effective control of knowledge and skills of Bachelors of Science in Mining Engineering in all types of speech activity in an innovative approach. A system of innovative tests in running control has been developed and presented which can be used both in the classroom of a teacher with students at a University and in the conditions of remote online communication throughout the process of training bachelors in mining specialties. It has been found that the formation of a foreign-language professional communicative competence of a Bachelor of Science in Mining Engineering, among other things, depends on a well-designed and tested innovative system of items in a test form.
\end{abstract}

\section{Introduction}

At the present stage the trend of innovative development of higher professional education in Russia is dictated, first of all, by significant changes in modern society. Responding to the socio-economic state of society [1] the higher education system is being subjected to significant transformations which vectors are aimed at the moral, social and intellectual development of the individual. These transformations are becoming due to an innovative approach.

Thus the National doctrine of education until 2025 indicates the need to train specialists who have formed professional communicative competence and are good at innovative activity.

The formation of innovative activity of a future specialist in mining largely depends on the innovative competence of a teacher [2]. The innovative competence of a teacher is determined by his:

1) intelligence;

2) readiness for continuous development of his professional activities;

3) creative ability to create new ideas and transfer them to his practical field;

*Corresponding author: lebsv1965@mail.ru 
4) openness something new.

Therefore the chief aim of a teacher under the innovative approach is to choose new methods and forms of organization of the student's educational activities which should be aimed at the development of a person who is in tune for success. Thereby innovative activity is inseparably linked with scientific and methodological competences of a teacher and with educational and research competences of a student [3].

A question of developing and applying innovative pedagogical tools and technologies in the educational process is arising in this connection. This can be not only new information and communication technologies but also new methods and forms of pedagogical control in process of teaching.

The use of up-to-date methods and means of pedagogical control in the process of foreign language education at the University undoubtedly contributes to improving the quality assessment of students' foreign language learning as well as the formation of their foreign language professional communicative competence.

It is also obvious that the presence of competent control for the formation of foreignlanguage communicative competence of the student subsequently the future graduate of the University will create a favorable basis for personal-oriented and professionally-oriented growth which, in turn, will contribute to his demand and his competitiveness in the labor market in the mining industry.

\section{Materials and methods}

The purpose of our research is to develop and use innovative methods and techniques of running control to improve the quality of formation of foreign-language professional communicative competence at bachelors of mining science under innovative approach.

In the conditions of an innovative approach the result of the formation of students' professional communicative competence largely depends on the effectiveness of the methods and forms of control used in foreign language learning. To achieve this goal, a foreign language teacher should use innovative ideas based on existing methods applied in teaching practice as well as his own developments that have passed all the necessary stages of testing.

One of the examples of the teacher's own (innovative) developments regarding control methods can be subject-oriented tasks in the test form or so-called innovative tests. The term innovative test or item in the test form defines its essence: according to the old theory of test constructing it doesn't meet the requirements of a standard test because of its structure.

Nevertheless such a test can be successfully applied in the process of running control which is carried out at different time stages of learning to different types of speech activity. The effectiveness of such tests in running control is obvious, because they diversify the learning process making it more productive and motivated. From the point of view of meaning content in performing such tests the main goal is a result of subject's knowledge at a certain stage of training, i.e. what he already knows and what he can already do.

It should be noted that control by result (product) is based on the fact of completion non-completion of the task and quality level of this performance. Control by process consists in finding out all the operations, methods and actions by which the student received a certain result.

This type of control is of great importance in learning a foreign language as it allows you to identify erroneous operations of a particular student and to correct them individually in time. And this determines the level of professional communicative competence of the student. Moreover, control by process is the basis for the formation of a full-fledged selfcontrol and a self-rating of students. 
Despite the fact that innovative tests are non-standard they nevertheless meet all the requirements of pedagogical running control, namely its functions, principles and goals. Thus the following main functions are distinguished in the up-to-date pedagogical control:

1) The learning function of control is provided primarily by control tasks for speech skills or operations linked up with language material, i.e. it is aimed at the formation of communicative competence. The learning function of control is successfully used in test tasks. It mobilizes the student's intellectual, volitional and emotional efforts to perform a task with maximum efficiency and responsibility ensuring the strength and thoroughness of learning.

2) The diagnostic function of control is connected with results in learning, some reasons for understanding / misunderstanding of teaching material and operates throughout the learning process.

3) The corrective function of control ensures the adequacy of the used control techniques for the object being tested and verifies the level of the specified information for performing correct speech or language actions in which the teacher can make certain corrections if the incoming information is incorrectly interpreted by the student during the verification process.

4) The educational function of control is intended for forming the student's cognitive competence to the subject being studied, for the motivational basis of his educational and research competence, for the ability to organize properly his study and to realize selftesting.

5) The developing function of control contributes to the development of memory and thinking and it is designed to ensure the formation of professional communicative competence.

The main control principles for the innovative test are:

1) The validity of the test implies compliance with a strictly limited correspondence with the set learning task as far as any test task is aimed at checking the foreign-language professional communicative competence of students on a particular topic that needs to be learned.

2) The objectivity of the test characterizes its compliance with the objective quantitative assessment of results in the process of its implementation. While performing the test qualimetric index should be carefully developed in the classification system of students' learning. At the same time you should pay attention to the simple calculation of correct and incorrect responses of students.

3) The reliability of the test assumes the definiteness of results of the students' responses regardless of the proficiency level of foreign language communication competence and allotted time to administer a test.

4) The practicality of the test consists in its compliance with the educational goals and objectives in the process of implementation. A test item is considered to be practical only if it expresses the simplicity of the item formulation and its structure and does not make it difficult to understand while performing it and the procedure for selecting responses is simple for a testee and does not cause any questions. The practicality of the innovative test is also characterized by a minimum of time spent on the mental activity of the testee on how to perform items [4].

A classification principle of control organization can be attributed to innovative tests. The classification principle of the foreign language control organization in selection of its content indicates a certain degree of knowledge and skills according to learning levels which corresponds to certain requirements of the Russian federal state educational standard and key European competencies [5-6].

According to this principle, for example, to obtain a satisfactory mark on a foreign language a student must fulfill a series of tasks and requirements that are obligatory for the 
minimum level of receiving this mark shown in learning, and for increased and high mark he needs to perform tasks at a higher level.

As for the purpose of running control for formatting foreign-language professional communicative competence at bachelors in mining in the course of learning it can include so-called triad of goals which includes:

1) goal-setting;

2) goal-realizing;

3) goal affirming.

Goal-setting determines for what purposes and by what means control should be exercised relative to the formation of professional communicative competence at different stages of the educational process.

Goal-realizing occurs in the running control which determines if the level of competence mastering corresponds to learning goals.

Goal-affirming is used to interpret the results of control in managing educational and cognitive competence of students.

Taking into account all control requirements described above it should be noted that the formation of professional communicative competence of students in foreign language learning is largely due to reading.

Reading as one of the types of speech activity can be both a goal and the main means of transmitting information in learning to other types of speech activity. Therefore the effectiveness of this competence formation will depend on how successfully the developed new methods and techniques of running control will be applied in reading [7].

\section{Results and discussion}

At the present stage among the traditional methods of foreign language control it is not always easy for a university teacher to choose the method of control in reading that would contribute most effectively to the formation of professional communicative competence of a student as they provide only partially the possibility of its implementation.

Thus in the traditional method of running control a number of teachers use a reproductive set of control techniques (reading and interpretation / translation of the text, answers to questions to a text, closed-type test items with the choice of one correct response, full or partial text retelling) which in our opinion do not fully meet the requirements of communicative approach in teaching foreign language reading.

It is known that the frequent use of reproductive techniques of control in reading both in workshop and private work of students at home where the main principle is to check the transfer of ready-made knowledge to students from a teacher, does not develop the students' creation although to some extent it encourages them to get information.

From the point of view of psychology the student's mental activity from such frequent techniques of control begins to get used to this method of presenting and perceiving information as an ordinary process, and as a result, the student's motivational activity for learning is decreasing. As a result of it there is a decrease in independent activity of a student which is expressed in the partial mastering educational material and in the complete absence to make decision independently and to get knowledge.

To avoid this it is necessary to use innovative methods of control in learning foreign language reading. Thus the development of a system of items in a test form is of great importance. The maximum involvement of students in the process of obtaining knowledge for improving their professional communicative competence depends on this system.

There are certain requirements for creating the system of items in a test form:

1) the instruction for fulfillment of an item must be the same for all students;

2) the instruction must correspond to the form and content of an item; 
3) the formulation of an item should be built in a form of a logical statement;

4) the item elements must be correctly positioned;

5) the rules for evaluating responses to an item must be the same.

Besides this system should fully cover a teaching material to be studied, the tasks of which are consistent with the six levels of classification of students' cognitive activity according to B. Bloom's taxonomy which includes: 1) knowledge, 2) understanding, 3) application, 4) analysis, 5) synthesis, 6) evaluation [8].

The first level is knowledge which characterizes the lowest degree of training and refers to the memorization and reproduction of the studied material. Items in a test form here can be the following types of items to define the concept such as: test items of the faceted form to choose the correct response [9-11]; tests for ordering words in a sentence; matching tests; crossword-tests [12], etc.

The second level is understanding that is associated with a conscious perception of the educational text, the ability to explain it using interpretation, paraphrasing the main idea, comparison. This level also involves a student to reproducing text that is small in content. Items will be here: tests for paraphrasing; tests for the correct sequence of words in a sentence or sentences in the text; interpretative questions about the content of the text; simple facet test items of an open type.

The third level is application which requires of the student to be able to apply the acquired knowledge either in familiar or new situations. At this stage you can offer students the following items: to edit the text; to restore the content of the text; to fulfill chain-test or cloze test.

The fourth level is analysis. This is the level of information processing analysis that forms high-level thinking skills of students. It involves the students' ability to break information into parts. You can offer tasks: to prepare a plan for the text; to prepare an annotation to the text; answers to analytical questions; answers to interpretative questions with a detailed answer.

The fifth level is synthesis. This thinking level forms an ability to generalize and combine elements to create a new product. Such a product can be a message on the topic to be studied: a speech; presentation; report; scheme; tasks for setting evaluation questions.

The sixth level is evaluation. This is the highest level of speech activity which involves students to apply their creative activities in new conditions. This level shows the formation of a foreign language professional communicative competence of students. Tasks for this level are: description of geological processes; writing articles; participation in project activities of students; participation in student scientific conferences held in foreign languages.

It should be noted that a choice of items is determined by the choice of learning goals, what kind of skills need to be tested at a certain stage of learning so such skills should be used for testing.

In order to understand the system of items in a test form better which is successfully used by the authors of this article in the practice of foreign language teaching let's give one of the examples of a developed workshop on topic "Igneous Rocks", the aim of which is to form a foreign language professional communicative competence of students studying mining. Some tasks will be reduced because of the large volume.

I. Study the vocabulary attentively.

II. Do Computer Vocabulary Crossword Test 1.

III. Do Computer Vocabulary Crossword Test 2.

IV. Read the first two paragraphs of text "Igneous Rocks" and do a facet test item.

V. Read text "Igneous Rocks" attentively to fulfill the chain-test given below.

Igneous rocks have crystallized from solidified magma. 
Igneous rocks can be classified in a number of ways and one of is based on mode of occurrence. They occur either as intrusive (below the surface) bodies or as extrusive masses solidified at the Earth's surface. The terms intrusive and extrusive refer to the place where rocks solidified.

The grain size of igneous rocks depends on their occurrence.

The intrusive rocks generally cool more slowly than the extrusive rocks and crystallize to a larger grain size. The coarser-grained intrusive rocks with grain size of more than 0.5 $\mathrm{mm}$ called plutonic or abyssal are referred to as intrusive igneous rocks because they are intruded into older pre-existing rocks. Extrusive or volcanic rocks have even finer grains, less than $0.05 \mathrm{~mm}$ and are glassy.

The largest bodies of igneous rocks are called batholiths. Batholiths cooled very slowly. This slow cooling permitted large mineral grains to form. As is known, granites and diorites belong to the group of intrusive or plutonic rocks formed by solidification of igneous mass under the Earth's crust.

Pegmatites (quartz, orthoclase and mica) also belong to the group of plutonic or intrusive rocks. They occur in numerous veins which usually cut through other plutonites, most often granite, or adjacent rocks.

Laccoliths and sills, which are very similar, are intruded between sedimentary rocks. Sills are thin and they may be horizontal, inclined or vertical. Laccoliths are thicker bodies and in some cases they form mountains.

Extrusive igneous rocks have been formed from lava flows which come from fissures to the surface and form fields of volcanic rocks such as rhyolite, andesite, basalt, as well as volcanic ashes and dust, tuff, etc. As a rule, these rocks of volcanic origin cool rapidly and are fine-grained.

VI. Solve the problem. While writing your report on igneous rocks your computer caught a virus which has damaged your text. Your task is to reconstruct the text for 10 minutes.

Igneous rocks $* *$ richinminerals that $*^{*} *$ import ++ ! economica\&\&y orhave gr\%\% $\% \%$ $\mathrm{s} *$ ientif** value. $\% \%$ neousrocks \& theirveinsarerichiniron, gold, $\mathrm{z}^{*} \mathrm{nk}, \mathrm{n} \mathrm{n}^{*} \mathrm{l} \&$ other fe??ous $\mathrm{m} / / / / \mathrm{s} . .$.

VII. Make up an annotation to the text "Igneous Rocks" using expressions on page ... .

VIII. Click on this reference http://onlineresize.club/pictures-club.html to determine visually types of rocks which don't belong to igneous rocks according to the given geological samples. Describe with your own words the differences between:

1) igneous rocks and sedimentary rocks;

2) igneous rocks and metamorphic rocks.

IX. Make up a report on igneous rocks in the form of presentation to take part in a classroom conference will be held next week.

\section{Conclusion}

In conclusion, the following should be mentioned:

1. Success in the formation of foreign-language professional communicative competence at bachelors of science in mining engineering in an innovative approach undoubtedly depends on modern control methods and innovative technologies that are being used today.

2. The development and use of innovative tasks in a test form, as well as innovative methods and techniques of control in foreign language learning have a positive impact on the educational activities of students.

3. Innovative test items in foreign language learning make students analyze, generalize and evaluate their foreign language competence in unfamiliar or changed situations. 


\section{References}

1. S. Zhironkin, M. Gasanov, G. Barysheva, E. Gasanov, O. Zhironkina, G. Kayachev, E3S Web Conf., 21, 04002 (2017)

2. A. Frey, Verlagsgruppe Beltz, 50, 903-925 (2004)

3. J. V. Hardt, Innovationskompetenz: Entwicklung und Validierung eines neuen Konstrukts (Universität Siegen, Siegen, 2011)

4. A. J. Lawson, Testing the TOEIC: Practicality, Reliability and Validity in the Test of English for International Communication (The University of Birmingham, Birmingham, 2008)

5. H. Walo, Key Competencies for Europe (CDCC, Strasbourg, 1997)

6. Common European Framework of Reference for Languages: Learning, Teaching, Assessment (Language Policy Unit, Strasbourg, 2001)

7. L. Fedyanina, S. Lebedintsev, V. Gustov, E3S Web Conf., 41, 04042 (2018)

8. B. S. Bloom, Taxonomy of Educational Objectives: The Classification of Educational Goals (David Mc Kay, New York, 1956)

9. S. Lebedintsev, L. Fedyanina, V. Gustov, E3S Web of Conferences 105, 04005 (2019)

10. H. Sh. Ahmadi, Y. Ozek, E. Demirel, The Sequence of Modules: A Facet in Language Proficiency Testing (Literature, Istanbul, 2012)

11. M. Rahimi, The Reading Matrix, 7:1, 151-165 (2007)

12. S. Bangera, L. R. Kumar, P. Thalenjeri, Archives of Medicine and Health Sciences, 3:1, 127-130 (2015) 